\title{
Development of Receptions Purposeful Management of Soil Fertility in Northern Kazakhstan
}

\author{
Kuralai Tynybaeva ${ }^{1}$, Abdulla Saparov $^{2}$, and Temirbulat Dzhalankuzov ${ }^{3}$
}

\begin{abstract}
The long cultivation of the chernozem soils has led to significant negative changes in the environment. It causes the need to develop measures that prevent violation of environmental conditions and contribute to the restoration of the ecological balance.Tillage is one of the main elements of farming systems. The traditional system of farming using plowing causes the destruction of soil structure. In Kazakhstan, every third hectare is susceptible to erosion that is from 50 million hectares under directly cereal crops about 27 million hectares is eroded. Resource-saving technologies (zero and minimum tillage) are the leading trend in the cultivation of crops. In the global agricultural sector zero technology is used on more than 94 million hectares.
\end{abstract}

Keywords - zero tillage, minimum tillage, traditional tillage, soil density, moisture reserves.

\section{INTRODUCTION}

$\mathrm{T} \mathrm{N}$ the context of the sovereignty of the Republic of Kazakhstan an integral part of building an effective market economy is the country's food security (Nazarbayev N.A., 1997, 1999). One of the main indicators of the country's economy, its independence and autonomy, has always been the production of grain. For grain production Kazakhstan has unique natural conditions that allow cultivation of strong and solid varieties of wheat with high technological quality.

Resource and moisture saving technology is the guiding direction of the cultivation of grains and oilseeds. Today, in the world with zero and minimum technologies are being processed about 60 million hectares and 200 million hectares of land, respectively, and the volume of the area is steadily increasing. The resource-saving technologies include minimum tillage and zero tillage. The resource-saving technology provides the usage of the safe protection of plant, thus preserves the ecological purity of the environment. Creating the mulch of crop residues at the surface of soil can restore and maintain beneficial microflora and fauna, increasing the biological activity of soil.

The main task of agriculture is a sustainable increase of the production of high quality and competitive (cheap) crop production with maintaining and increasing soil fertility. The basis of the solution of this problem is the efficient use of soil

\footnotetext{
${ }^{1}$ Kazakh National Agrarian University, Almaty, Kazakhstan

${ }^{2}$ Kazakh U.Uspanov Research Institute of Soil Science and Agricultural Chemistry, Almaty, Kazakhstan.
}

and climatic resources of the region and the adaptation of resource-saving tillage systems.

Resource-saving technologies include minimum tillage (the mulch sowing) and zero tillage (direct sowing) technologies.

The minimum tillage includes one or numbers of tillage made by cultivators or/and disc harrows. Straw and stubble are situated on the top layer of soil as the mulch. Sowing is carried out on the basis of finely processed soil with the creation of mulch layer of plant residues and crumbly soil [1].

Direct sowing is carried out in the stubble without any tillage. The explanation for the use of resource-saving technologies is that soil with high humus content $(3.5 \%$ and more) do not require intensive processing for controlling agro processes. They are able to maintain an optimal density for many kind of crops under the influence of natural factors (1$\left.1,24 \mathrm{~g} / \mathrm{cm}^{3}\right)$ [2]. During the selection of the main and surface soil cultivation in summer-autumn and spring-summer periods should take into consideration that most preferred in order to maintain moisture aligned fine lumpy state. Lumpy and dusty surface sharply increase the soil moisture loss. Lumpy soil surface also helps to increase the evaporation of moisture. In periods of intensive evaporation of moisture from the soil, preferably compressed (natural) addition of the ploughing layer.

The implementation of these principles, directing to accumulation and storage of moisture in the summer postharvest period may mostly provide shallow tillage. In springsummer period the best conservation and rational use of moisture are achieved by creating of fine lumpy surface layer, by reduction of number and depth of loosening, by combining technological operations working on one aggregate.

The basis of resource-saving technologies of cultivation of agricultural crops is renunciation of the use of a plow. This set of methods aimed at combating the degradation of the soil structure, reducing fertility, improving water balance and falling crop yield [3].

Leaving stubble and straw on the field surface creates favorable conditions for the detention of snow, and reducing the depth of freezing, decreasing moisture evaporation from the soil. Creating a mulch of stubble remains and straw in direct seeding can not only improve the water regime, but also can restore soil fertility.

In connection with the number of objectively prevailing circumstances, resource-saving technology under current 
conditions stands as one of the priorities in the restructuring of reference methods of crop.

The main principles of resource-saving technologies:

- Minimization or renunciation of mechanical tillage;

- The preservation of plant residues on the soil surface;

- The use of quality seeds, responsive to these technologies.

The necessary and important aspect of preserving technologies is the use of crop residues. To date, there are cases of burning of straw and crop residues. At the same time, the straw is an important source of organic fertilizer, contributes the restoration of humus in the soil, is the irreplaceable mulching means of protection against moisture loss, that is a kind of copying the natural biological mechanism.

\section{MATERIALS AND METHODS}

At the end of May in 2015 researches were conducted on the experimental fields of Kustanai Agricultural Research Institute with itinerary key and stationary methods. At zero and minimum tillage were studied: morphogenetic indicators of southern chernozem, water-physical properties of southern chernozem (the average percentage of moisture, the average density of the soil, the overall porosity, air supply and the reserves of moisture, etc. (fig. 1).

The experimental scheme consists of the following variants:

1. Minimum tillage technology: includes processing after harvest with flat carving under $0-12 \mathrm{~cm}$;

2. Zero tillage technology: crop residues in autumn (stubble and chopped straw) are preserved on the field surface and they help to snow retention, improve soil structure and accumulation of nutrients. Sowing is carried out on the raw field with the rejection from all kinds of mechanic tillage.
The researches of soils are carried out by the following methods: morphogenetic indicators by field method (), the density of ploughing layer of soil by Kaczynski method (the method of volumetric weight) (3), soil moisture and preservation of productive moisture with thermostatic weight method (4). The mathematical processing of statistical data held by V.A. Dospekhov [4].

\section{THE RESULTS OF RESEARCHES AND DISCUSSION}

Numerous domestic and foreign experiences show that the transition to modern technology with energy-saving methods of soil cultivation make it possible to avoid the deterioration of physical and agrochemical properties of soils, leading to deterioration of plant growth conditions.

To determine the morphogenetic changes in the profile of the key sections of southern chernozem were laid at: section \#3 - zero tillage, and section \#4 - minimum tillage.

Section \#3 - zero tillage, laid in $3.5 \mathrm{~km}$ to the east of Zarechnoye village. The plain with shallow depressions. At the bottom of the section is the moist light loamy soil with nests of gypsum and sand layers. The humus horizon capacity $\mathrm{A}+\mathrm{B}=$ $68 \mathrm{~cm}$. Boiling for streaks from $41 \mathrm{~cm}$, for wedges $25 \mathrm{~cm}$. Single carbonate secretion from $34 \mathrm{~cm}$. Abundant carbonate secretion accumulation from $51 \mathrm{~cm}$ to $110 \mathrm{~cm}$. The depth of section is $120 \mathrm{~cm}$ (fig. 1).

Section \#4 - minimum tillage. Section is near the zero tillage site, which is located in $3.5 \mathrm{~km}$ from the Zarechnoye village. Boiling for streaks $-40 \mathrm{~cm}$, for wedges $-49 \mathrm{~cm}$. The carbonate secretion in the form of white-eye and blurry spots from 60$120 \mathrm{~cm}$. At the bottom are the pale-yellow sandy loam and gray or greenish clay (fig. 1). 


\section{Section \#3, Zero tillage.}

A tillable 0-25 cm: The dark gray, dense, humid, dusty, lumpy, permeated with roots, explicit transition in density and structure.

B $_{1}$ 25-48 cm: The dark gray with brownish- dark gray wedges, humus streaks are narrow, dense, lumpyprismatic, with rare roots, transition is clear.

$B_{2}$ 48-68 cm: Brownish dark gray, weakly prismatic lumpy, unit roots, light loam, gradual transition.

BC $68-89$ cm: Brownishyellow earth, abundant carbonate secretion, sandy loamy, a sharp transition.

$C_{1} \mathbf{8 9 - 1 2 0} \mathrm{cm}$ : Yellowish brown loamy sand with abundant carbonate secretion, there are found rusty spots of iron and gypsum crystals.

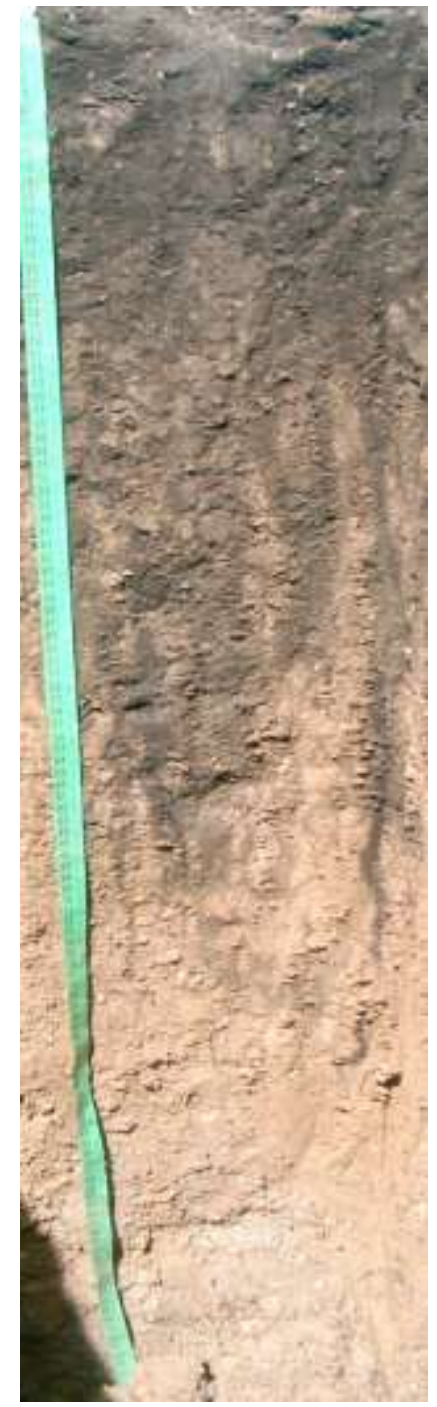

Section Minimum tillage.

A tillable 0-26 cm: The dark gray, loose, pulverescent lumpy, middle loamy, sharp transition in density and structure.

B 26-49 cm: The dark gray, with brownish-dark gray wedges, prismatic lumpy, dense, transition is clear.

$B_{2}$ 49-73 cм: Brownish - dark gray with wedges, weakly prismatic, light loam, dense, visible transition.

ВC 73-94 см: Brownish-yellow earth with humus tongues with band sands, dense with abundant carbonate as white-eye.

$C_{1}$ 94-130 cm: Playyellow clay with rusty spots of iron; gypsum crystals are found.

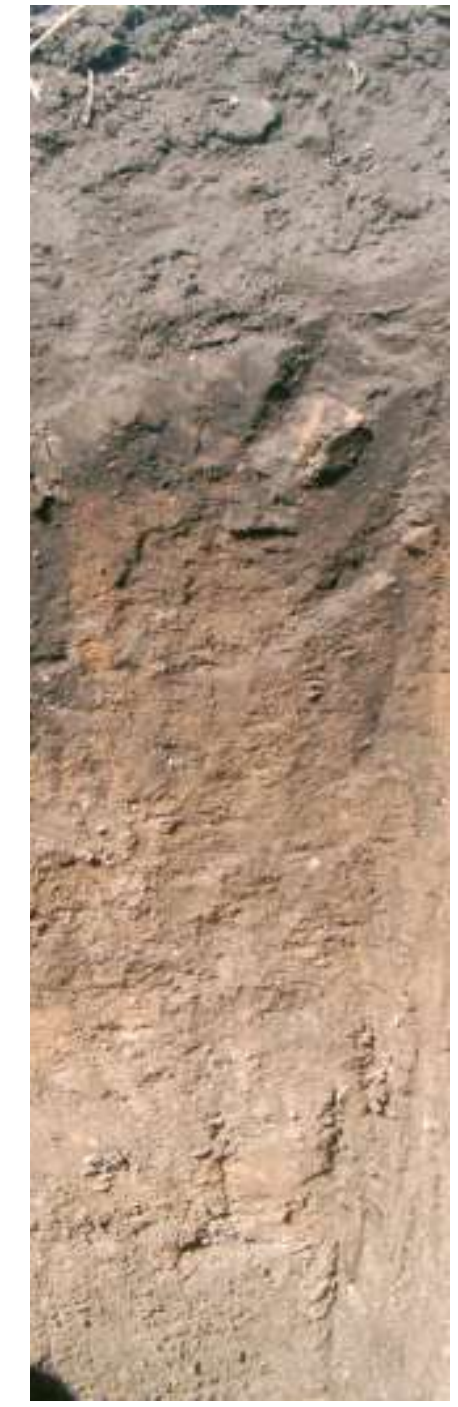

Fig.1. The southern light loamy chernozem during minimum and zero tillage

Thus, virtually sections \#3-4 represent the southern light loamy chernozem and close to the middle loamy chernozem. Considered the southern light loamy chernozem refers to satisfactory arable soils, but in most cases are subject to wind erosion, and while using them the use of complex of antierosion measures to enrich them is required.

Interest in water-physical properties of the soil is related to the issues of farming, rational use of agricultural machinery and tillage methods, with desire to get the optimum ploughed field for cultivated plants. Also, water-physical properties of soil greatly affect to the growth and development of plants, and consequently, to the quantity of the crop.
TABLE 1. Water-physical properties of southern chernozem of Kustanai region (Zarechnoye village) under different tillage

\begin{tabular}{|c|c|c|c|c|c|}
\hline $\begin{array}{c}\text { Layer } \\
\text { of } \\
\text { soil, } \\
\mathrm{cm}\end{array}$ & $\begin{array}{c}\text { The average } \\
\text { percentage } \\
\text { of moisture, } \\
(\%)\end{array}$ & $\begin{array}{c}\text { The } \\
\text { average } \\
\text { density } \\
\text { of the } \\
\text { soil, } \\
\left(\mathrm{g} / \mathrm{cm}^{3}\right)\end{array}$ & $\begin{array}{l}\text { The } \\
\text { total } \\
\text { porosity, } \\
(\%)\end{array}$ & $\begin{array}{c}\text { The air } \\
\text { provisio } \\
\mathrm{n}(\%)\end{array}$ & $\begin{array}{c}\text { Moistur } \\
\text { e } \\
\text { reserves, } \\
\mathrm{mm}\end{array}$ \\
\hline \multicolumn{6}{|c|}{ Zero tillage (spring wheat) } \\
\hline $0-10$ & 22,3 & 0,98 & 63 & 21,85 & 21,85 \\
\hline $\begin{array}{l}10- \\
20\end{array}$ & 27,1 & 1,09 & 59 & 29,54 & 29,54 \\
\hline $\begin{array}{l}20- \\
30\end{array}$ & 28,7 & 1,09 & 59 & 31,28 & 31,28 \\
\hline $\begin{array}{l}30- \\
40\end{array}$ & 27,0 & 1,04 & 61 & 28,08 & 28,08 \\
\hline $\begin{array}{l}40- \\
50\end{array}$ & 24,8 & 1,11 & 58 & 27,28 & 27,53 \\
\hline $0-50$ & & & & & 138,28 \\
\hline \multicolumn{6}{|c|}{ Minimum tillage (spring wheat) } \\
\hline $0-10$ & 14,7 & 1,10 & 58 & 16,17 & 16,17 \\
\hline $\begin{array}{l}10- \\
20\end{array}$ & 16,7 & 1,31 & 50 & 21,88 & 21,88 \\
\hline $\begin{array}{l}20- \\
30\end{array}$ & 15,1 & 1,35 & 49 & 20,39 & 20,39 \\
\hline $\begin{array}{l}30- \\
40 \\
\end{array}$ & 13,9 & 1,37 & 48 & 19,04 & 19,04 \\
\hline
\end{tabular}




\begin{tabular}{|c|c|c|c|c|c|}
\hline $\begin{array}{l}40- \\
50\end{array}$ & 15,2 & 1,22 & 54 & 18,54 & 18,54 \\
\hline $0-50$ & & & & & 96,02 \\
\hline \multicolumn{6}{|c|}{ Traditional tillage (Fallow land) } \\
\hline $0-10$ & 15,3 & 1,08 & 59 & 16,52 & 16,52 \\
\hline $\begin{array}{l}10- \\
20\end{array}$ & 20,7 & 1,05 & 60 & 21,74 & 21,74 \\
\hline $\begin{array}{l}20- \\
30\end{array}$ & 22,2 & 1,05 & 60 & 23,31 & 23,31 \\
\hline $\begin{array}{l}30- \\
40\end{array}$ & 19,5 & 1,12 & 58 & 21,84 & 21,84 \\
\hline $\begin{array}{l}40- \\
50\end{array}$ & 19,6 & 1,16 & 56 & 22,74 & 22,74 \\
\hline $0-50$ & & & & & 106,15 \\
\hline
\end{tabular}

In the steppe zone of Kazakhstan negative factors, reducing yields of cereal crops, are the lack of moisture, weeds and soil erosion.

In the context of the North-Kazakhstan region soil moisture is one of the key factors to ensure the plants with water. Soil moisture is the only guaranteed source of water supply to the plants during the vegetation period. According to long-term data, water consumption of spring wheat from the one-meterdeep layer during the vegetation period is determined by an average of $2679 \mathrm{tn} / \mathrm{ha}$ (P.M. Fokeyev, 1961).

Change loosening, reducing soil density, increases the aeration, and with it the loss of soil moisture through the diffusion of water vapor. The use of effective herbicides also reduces the loss of soil moisture, reduces weed infestation of fields and reduces soil erosion, deflation precious silt with high humus content.

Types of soil treatments significantly affect the reserves of soil moisture and its dynamics. The search for new tillage technologies with a glance to preserving the basic soil parameters () showed that the most optimal parameters of soils are formed under zero tillage in comparison with traditional and minimum tillage. And, our researches have shown the correctness of these theoretical data.

Analyses have shown that when using of resource-saving technologies of tillage the average moisture percentage is more than traditional tillage's. For example, at zero tillage the average moisture percentage fluctuates from $22.3(0-10 \mathrm{~cm})$ to $28.7 \%(20-30 \mathrm{~mm})$, and at minimum tillage from $13.9(30-40$ $\mathrm{cm})$ to $16.7 \%(10-20 \mathrm{~cm})$. At traditional tillage, the indicator fluctuates from $14.7(0-10 \mathrm{~cm})$ to $20.7(10-20 \mathrm{~cm})$. At all kinds of tillage the maximum indicator of the average moisture content at the depth of 10-20, 20-30 cm (fig. 2.)

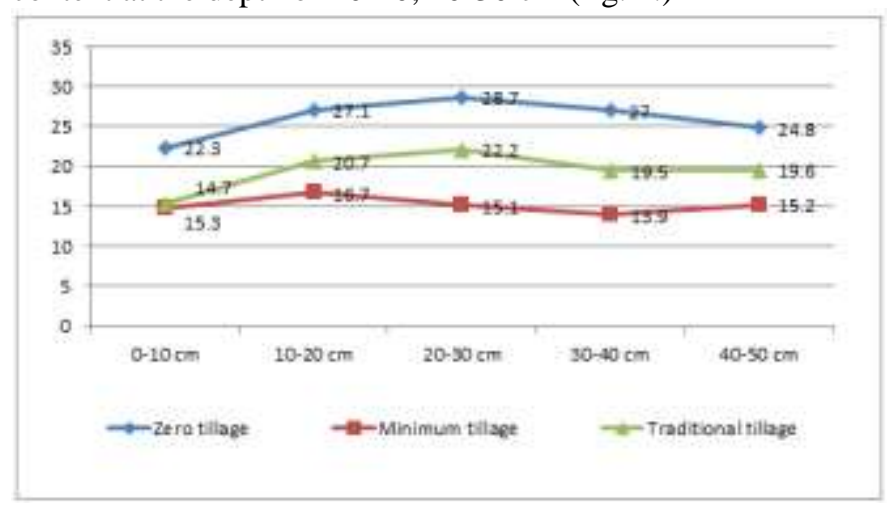

Fig. 2. The average moisture $\%$
The values of average soil density at zero, minimum and traditional tillage are characterized as follow: at zero tillage on $0-10 \mathrm{~cm}$ the soil density is $0.98 \mathrm{~g} / \mathrm{cm}^{3}$ and $1.11 \mathrm{~g} / \mathrm{cm}^{3}$, respectively, reaches a maximum in the layer of $40-50 \mathrm{~cm}$, at minimum tillage $-1.1 \mathrm{~g} / \mathrm{cm}^{3}$ and $1.37 \mathrm{~g} / \mathrm{cm}^{3}$, respectively, and at traditional tillage $-1.08 \mathrm{~g} / \mathrm{cm}^{3}$ and $1.16 \mathrm{~g} / \mathrm{cm}^{3}$, respectively; the most favorable conditions for moisture and density of southern chernozem are formed at zero tillage (fig 3).

Soil density was on the optimal level according to scientific data, where the optimal density of southern chernozem for most crops is 1.0 to $1.3 \mathrm{~g} / \mathrm{cm}^{3}$. When loose $(0.9 \mathrm{~g} / \mathrm{cm} 3)$ and very dense $\left(1.5 \mathrm{~g} / \mathrm{cm}^{3}\right)$ constitution, the yield of grain crops decreases significantly (P.K. Ivanov, L.I. Korobova 1969, D.I. Burov 1970, G.I. Kazakov 1990 and others) [5, 6].

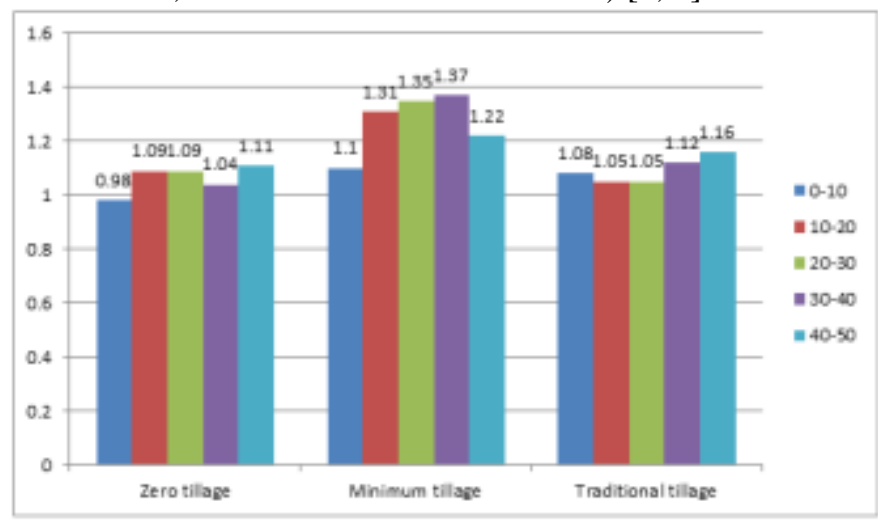

Fig. 3. The average density in half-meter layer of soil, $\mathrm{g} / \mathrm{cm}^{3}$

One of the main problems in the dry steppe zone is provision of moisture during the cultivation of crops $[7,8]$.

In spring period, the moisture reserves in half-meter layer of soil are characterized differently. For example, at traditional tillage the moisture reserve is 106.15 , at minimum tillage is 96.02 , at zero tillage is $138.28 \mathrm{~mm}$. In spring zero tillage prevails with its moisture reserves, as well as on other indicators.

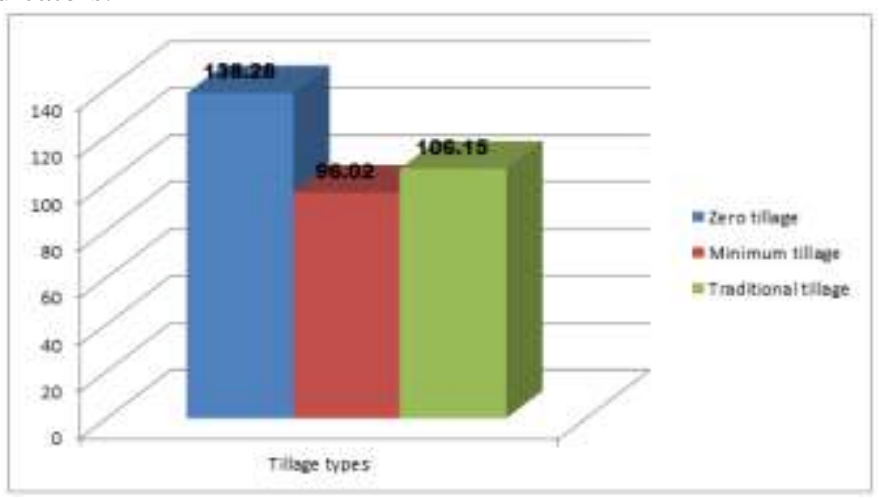

Fig. 4. Moisture reserves at different tillage types, $\mathrm{mm}$

The explanation for the application of minimum and zero tillage is that southern chernozem normal soil under grain production does not require intensive tillage to control its agrophysical properties.

\section{CONCLUSION}

1. Decreasing of number of mechanical tillage and its completely exclusion does not lead to repacking of soil more 
than the high optimal values. At zero tillage on $0-10 \mathrm{~cm}$ the soil density fluctuates from $0.98 \mathrm{~g} / \mathrm{cm}^{3}$ to $1.11 \mathrm{~g} / \mathrm{cm}^{3}$, at minimum tillage $-1.11 \mathrm{~g} / \mathrm{cm}^{3}$ and $1.37 \mathrm{~g} / \mathrm{cm}^{3}$, and at traditional tillage $-1.08 \mathrm{~g} / \mathrm{cm}^{3}$ and $1.16 \mathrm{~g} / \mathrm{cm}^{3}$, respectively. The most favorable conditions for moisture and density of southern chernozem are formed at zero tillage.

2. If you are using resource-saving tillage technology the average percentage of moisture is more than the traditional tillage. At zero tillage the average percentage of moisture fluctuates from $22.3(0-10 \mathrm{~cm})$ to $28.7 \%(20-30 \mathrm{~cm})$, and at minimum tillage from $13.9(30-40 \mathrm{~cm})$ to $16.7(10-20 \mathrm{~cm})$. At traditional tillage, this indicator fluctuates from $14.7(0-10 \mathrm{~cm})$ to $20.7(10-20 \mathrm{~cm})$.

3. Minimizing and complete elimination of mechanical processing favor to the accumulation of autumn-winter settling. Before sowing in the variant with zero tillage the moisture reserves are $138.28 \mathrm{~mm}$, much more than the other variants.

4. Minimum and zero tillage technologies contribute improving the water regime, provide safe protection of soil from erosion.

\section{REFERENCES}

[1] V.A. Bankin. "Resource-saving technologies - the future of Russian agriculture", Agriculture, vol.1, pp.12-13, 2006.

[2] N.M. Bakayev, Soil moisture and harvest, Almaty, 1975, 135p.

[3] S.A. Verigo, A.A. Razumov, Soils moisture, Almaty: Gidrometeoizdat, 1973.

[4] S.I. Galevich, J.V. Tulaev, T.M. Aksagov, "Vlago resource-saving technologies in the north of Kazakhstan", Herald of science Kazakhstan, vol.9, pp.36-40, 2010.

[5] T.D. Dzhalankuzov, "Zero tillage technique used in northern Kazakhstan and its main results", in "Recent advances in tillage conditions rainfed agriculture: Equipment and Technologies" Kazakhstan international scientific-practical conference, Astana, 2015, pp.14-15.

[6] T.D. Dzhalankuzov, A.S. Saparov, "Monitoring studies of basic parameters of black earth soils at zero and minimum tillage", in «NoTill and crop rotation - the basis of agricultural policy support conservation agriculture for sustainable production intensification" Coll. proceedings of the international conference, Astana - Shortandy, 2009, pp.96-104.

[7] B.A.Dospekhov, The methodology of experimental work, Moscow, 1985, pp. 223-301

[8] E.J. Deibert, Therole soil physical properties in managing rtduce tillage systems.- Norht Dakota farm regearch, v. 41, p.30-33, 1983. 